\title{
THREATENED FISHES OF THE WORLD: Orsinogobius croaticus (Mrakovčić, Kerovec, Mišetić and Schneider, 1996) (Teleostei: Gobiidae)
}

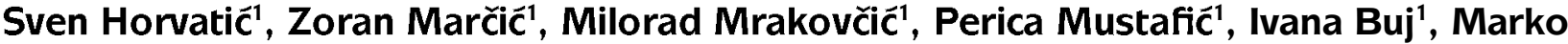 \\ Caleta ${ }^{2}$, Davor Zanella ${ }^{*}$
}

'University of Zagreb, Faculty of Science, Department of Zoology, Rooseveltov trg 6, 10000 Zagreb, Croatia ${ }^{2}$ University of Zagreb, Faculty of Teacher Education, Savska cesta 77, 10000 Zagreb, Croatia

*Corresponding Author, Email: davor.zanella@biol.pmf.hr

\section{ARTICLE INFO}

Received: 24 February 2016

Received in revised form: 15 November 2016

Accepted: 14 December 2016

Available online: 20 January 2017

Keywords:

Neretva dwarf goby

Fragmentation

Habitat preservation

\section{ABSTRACT}

Orsinogobius croaticus is a freshwater fish with a small and limited distribution range in the Adriatic basin in Croatia and Bosnia-Herzegovina, where it inhabits cold karstic rivers and springs. The main threats to its populations include habitat fragmentation, declining habitat quality and the introduction of alien species. Conservation recommendations are proposed to improve effective habitat preservation and to expand the knowledge about this species.
How to Cite

\section{SYNONYMS}

None

\section{COMMON NAMES}

Vrgoračka gobica (Cro)

Neretva dwarf goby (Engl)

\section{TAXONIMIC NOTES}

This species was originally described as Knipowitschia punctatissima croatica. It has been transferred to the genus Orsinogobius, as O. croaticus, by Geiger et al. (2014).
Horvatić, S., Marčić, Z., Mrakovčić, M., Mustafić, P., Buj, I., Ćaleta, M., Zanella, D. (2017): Threatened fishes of the world: Orsinogobius croaticus (Mrakovčić, Kerovec, Mišetić and Schneider, 1996) (Teleostei: Gobiidae). Croatian Journal of Fisheries, 75, 30-35. DOI: 10.1515/cjf-2017-0006. 


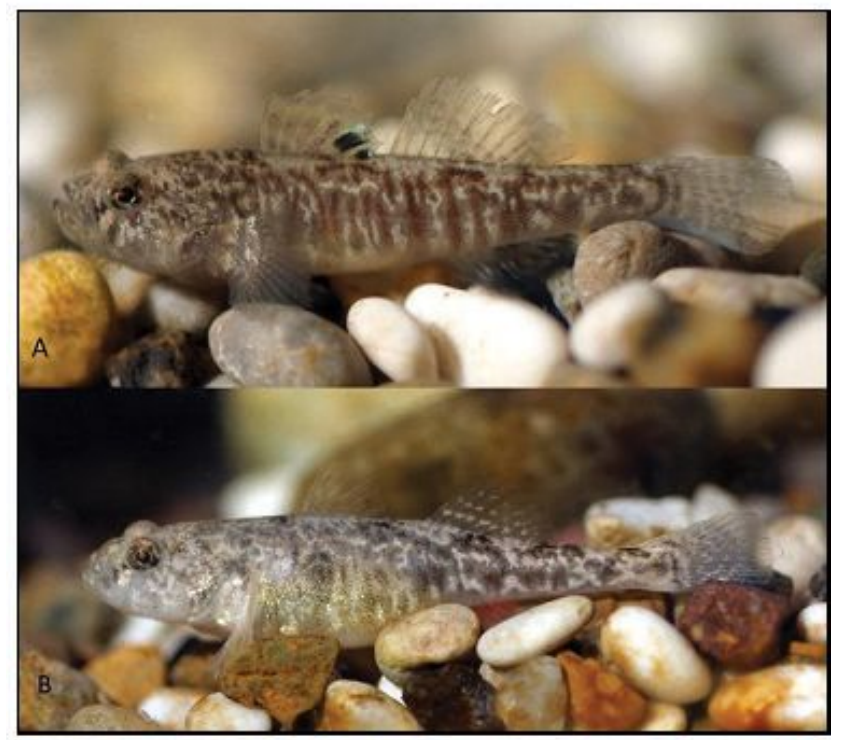

Fig 1. Male (A) and female (B) Orsinogobius croaticus (photo by Perica Mustafić, June 2006) lower Neretva drainage catchments in Croatia and BosniaHerzegovina, including the Trebižat River, Bregava River and Hutovo Blato wetland (Mrakovčič et al., 2006; Šanda and Kovačic, 2009) (Table 1). It should be noted that no individuals have been recorded in Modro Oko Lake since 1997, and it is believed that prior reports were the result of incidental translocation via subterranean water flows from the Neretva River.

Mrakovčić et al. (2006) list O. croaticus as critically endangered (CR) in Croatia due to declining abundance, continued diminishing of the distribution range, declining habitat quality and a strong impact from alien species (criteria: A1ace). It has been included in the IUCN Red List as vulnerable (VU) since 1996 (IUCN, 1996). Detailed quantitative studies on these subpopulations are needed so as to ascertain the existence, actual abundance and stability of subpopulations.

Table 1. List of locations where $O$. croaticus was found in Croatia and Bosnia-Herzegovina, with core areas and their associated area of occupancy (AOO)

\begin{tabular}{|c|c|c|c|c|}
\hline & Locations & Core area & $\mathrm{AOO}\left(\mathrm{km}^{2}\right)$ & References \\
\hline 1. & Bregava River & \multirow{4}{*}{ Neretva River (B-H) } & \multirow{4}{*}{24} & \multirow{4}{*}{ Šanda and Kovačić, (2009) } \\
\hline 2. & Trebižat River (Teskera) & & & \\
\hline 3. & Trebižat River (Kravica waterfalls) & & & \\
\hline 4. & channel in Hutovo Blato wetland & & & \\
\hline 5. & Metković City & \multirow{3}{*}{ Neretva River (Croatia) } & \multirow{3}{*}{20} & \multirow{3}{*}{$\begin{array}{l}\text { Mrakovčić et al., (1996, 2006); Crivelli, } \\
\text { (2006); Kottelat and Freyhof, (2007); Čaleta } \\
\text { et al., (2015) }\end{array}$} \\
\hline 6. & Modro Oko Lake & & & \\
\hline 7. & Mlinište village & & & \\
\hline 8. & Norin River & Norin River & 4 & Mrakovčić et al., $(1996,2006)$ \\
\hline 9. & Baćina Lakes & Baćina Lakes & 8 & $\begin{array}{l}\text { Mrakovčić et al., (1996, 2006); Crivelli, } \\
\text { (2006); Kottelat and Freyhof, (2007) }\end{array}$ \\
\hline 10. & near Brečići village & \multirow{4}{*}{$\begin{array}{l}\text { Matica River (Polje Jezero } \\
\text { field) }\end{array}$} & \multirow{4}{*}{20} & \multirow{4}{*}{$\begin{array}{l}\text { Mrakovčić et al., (1996, 2006); Miller, } \\
\text { (2004); Crivelli, (2006); Kottelat and Freyhof, } \\
\text { (2007); Zanella, (2007); Čaleta et al., (2015) }\end{array}$} \\
\hline $\begin{array}{l}11 . \\
12 .\end{array}$ & $\begin{array}{l}\text { Krotuša field } \\
\text { near Crni Hum }\end{array}$ & & & \\
\hline 13. & Stinjevac spring & & & \\
\hline 14. & Vučija spring & & & \\
\hline 15. & Vrgorac city & $\begin{array}{c}\text { Matica River (Rastočko } \\
\text { Polje field) }\end{array}$ & 4 & Šanda and Kovačić, (2009) \\
\hline
\end{tabular}




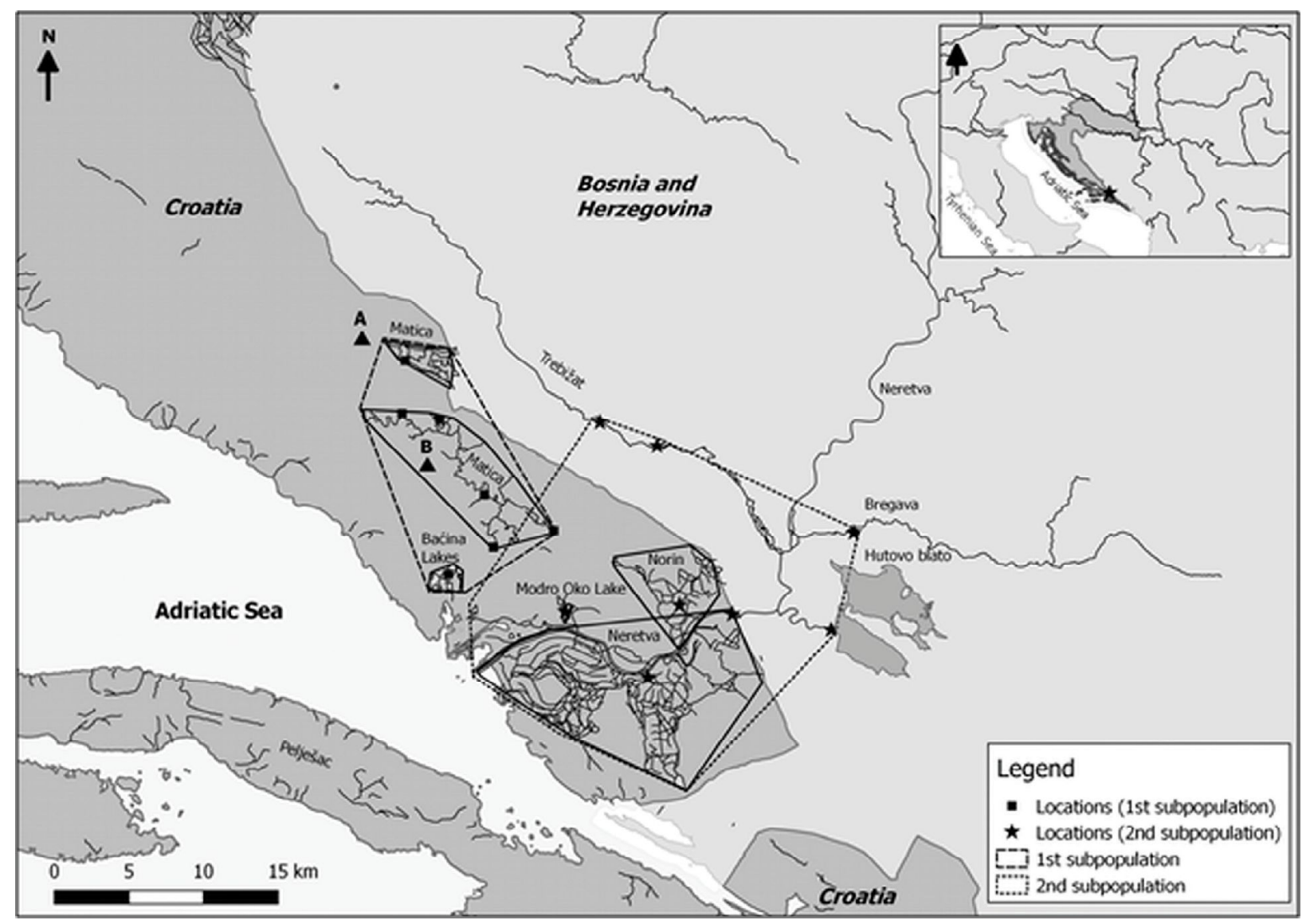

Fig 2. Geographical distribution of Orsinogobius croaticus

\section{HABITAT AND ECOLOGY}

Orsinogobius croaticus is a benthic freshwater species that occupies sandy bottoms with occasional stones and pebbles in clear karst rivers, slow-flowing streams and oligotrophic lakes. Occasionally, it can be found in brackish lakes (Baćina). Saline springs (i.e. Mindel) result in increased salinity in some parts of the lakes (i.e. Očuša Lake), which may reach $5 \%$ o. This species inhabits cold oligotrophic karst watercourses with a mean annual water temperature between 9.7 and $19.3^{\circ} \mathrm{C}$. The mean annual saturated oxygen level at all locations was $80 \%$ (with the exception of the Butina spring where autumn/winter levels dropped to $71 \%$ ) (Zanella, 2007). During winter and early spring, it inhabits small rivers and streams, but in summer when the rivers may completely dry out, it is assumed to retract underground, surviving in small ponds and refuges (Miller, 2004; Mrakovčić et al., 2006; Zanella, 2007). An example is the Matica River, a typical karst river with prominent seasonal fluctuations in the water regime. Sexually mature individuals appear in larger numbers only in the winter, when springs are full and rainwaters torrential. Spawning begins in February and March. Following spawning, adult individuals are less common in a watercourse and they are more difficult to capture, as confirmed by field studies. This is also true for other endemic species inhabiting seasonal karst watercourses and springs in Croatia (genera Telestes, Delminichthys, Squalius) (Miller, 2004; Mrakovčić et al., 2006; Kottelat and Freyhof, 2007). No data are available on migration patterns.

\section{BIOLOGY}

Orsinogobius croaticus is a small goby reaching up to 60 $\mathrm{mm} \mathrm{TL}$ and has a life span of less than two years. Sexual maturity in both males and females is achieved at about 40$45 \mathrm{~mm}$ TL, spawning occurs after the first winter (Kottelat and Freyhof, 2007; Zanella, 2007). The extended spawning season lasts from March to November, with the highest intensity between April and September (Zanella et al., 2011). During spawning, males produce drumming sounds (Zanella, 2007). It is assumed that $O$. croaticus is a multiple spawner, capable of producing several batches of eggs in a single reproductive season (Zanella et al., 2011), with a 
high variability in fecundity. Zanella (2007) determined three types of nests: (i) in naturally occurring round-shaped crevices in rocks, (ii) dug out openings in the substrate under rocks, and (iii) dug out holes in sandy and silty substrates. On gravelly substrates, where there is no natural shelter, it digs out oval-shaped openings to form nests, making this species more opportunistic than species of the genus Knipowitschia (i.e. K. longicaudata and K. panizzae which require shells or rocks to build nests). After the female lays eggs on the upper surface of the nest, the male aggressively guards the eggs and ventilates them by fanning with the caudal and pectoral fins (Kottelat and Freyhof, 2007; Zanella et al., 2011). Orsinogobius croaticus is an opportunistic carnivorous species, feeding on small aquatic invertebrates, mostly chironomid larvae and amphipods (Zanella, 2007).

\section{THREATS}

The major threats to $O$. croaticus populations are alien species and anthropogenic impacts, primarily caused by habitat fragmentation and declining habitat quality (Mrakovčić et al., 2006). Since the species is stenoendemic and may spend a part of its life underground, it is vulnerable to water pollution and eutrophication (Crivelli, 2006).

Direct threats within the species distribution range include:

I. Watercourse reclamation has the largest impact throughout Rastočko Polje field, which has been largely altered for agriculture. The Matica River has been connected with the Mlada River via a canal for irrigation purposes. In combination with the porous karst substrate, this has increased the likelihood for the inflow of pollutants into ground water.

II. Polje Jezero field is also affected by strong anthropogenic impacts. Intensive road construction works have taken place here recently and resulted in the widespread removal of deciduous vegetation and concrete reinforcement of river banks. Illegal fishing using minnow traps to capture indigenous ichthyofauna occurs throughout the Matica River. A main freeway lies in the vicinity.

III. The Neretva: the delta is a mosaic of diverse aquatic habitats (delta, lagoons, brackish habitats, canal networks, springs and streams, lakes). Anthropogenic pressure is high, particularly in the form of expansion of agricultural areas and changes of the water regime in floodplain areas. Neighbouring towns create a high pollution load on the river. The entire delta region is highly fragmented by the construction of roads and railways. Translocated and introduced alien species are a direct threat.
IV. Agricultural activities in the surrounding area have a negative impact on Baćina Lakes, primarily since various pollutants (mineral fertilisers, herbicides, heavy metals) drain directly into the lakes due to the karst character of the fields.

V. An additional problem is excessive fishing using all available gear and the lack of adequate controls. However, it is unclear if fishing leads to population depression.

VI. Melioration and channelling of watercourses to serve agriculture are the greatest threats to the Norin River. The introduction of alien species has negative impacts and poses a direct threat to the fauna of this area. Additional anthropogenic pollution from the nearby Neretva region also has a certain impact on the Norin River.

\section{USE AND TRADES}

This species has no direct economic or nutritional value (Zanella, 2007), however it is worth noting that the locals occasionally collect and consume this fish (Mrakovčic et al., 2006). Given the short lifespan of the species and the fact that individuals in surface waters in winter are mostly mature females, this could reflect negatively on the population.

\section{CONSERVATION ACTIONS}

Several previous studies have been conducted on the biology, ecology and life history of this goby (Mrakovčić et al., 2006; Zanella, 2007; Zanella et al., 2011). However, detailed knowledge of its genetics and abundance is required. As an endemic species, it is strictly protected pursuant to the Nature Protection Act (Official Gazette 144/13), though this protection is inadequate to address the threats the species faces. Its conservation status has been assessed as critically endangered (CR) in the Red Book of Freshwater Fish of Croatia (Mrakovčič et al., 2006). It has been included in the IUCN Red List as vulnerable (VU) in 1996. The species has also been listed as a NATURA 2000 species. All five core areas inhabited by $O$. croaticus are protected NATURA 2000 areas in Croatia, though no protected areas are known from its range in Bosnia-Herzegovina. Furthermore, the Neretva Delta in Croatia is protected under the Ramsar Convention and it is a special ornithological and ichthyological reserve at national level.

Here, alongside Zanella and Kovačić (2014), specific measures for the conservation of this species are proposed:

1. Prevent the reclamation and backfilling of waters, especially groundwater sources (springs Stinjevac and Vučja, Polje Jezero field).

2. Avoid any form of water and habitat pollution, 
particularly in the Neretva Delta and its tributaries (Norin River), including areas in the vicinity of large towns.

3. Install wastewater treatment plants to treat possible anthropogenic sources of pollution in the vicinity of the species habitat (particularly for large towns).

4. Limit watercourse regulation (especially amelioration) within the lower Neretva drainages.

5. Strictly prohibit the introduction of alien species (chub, stone moroko, pumpkinseed, black bullhead, pike); where they have already been introduced, regulate population size (Neretva Delta).

6. Prohibit waste disposal near springs (springs Stinjevac and Vučja) in Polje Jezero field.

7. Align the proposed water regulation plan for Polje Jezero field with monitoring and conservation plans for this species.

\section{RATIONALEFORTHE RED LISTASSESSMENT}

Detailed quantitative studies on the long term development of the abundance of Orsinogobius croaticus are yet to be set up. However, it is very clear that the populations are declining. This species has a naturally fragmented distribution range, both in Croatia and Bosnia-Herzegovina. At all five known sites, $O$. croaticus is strongly impacted by alien species. As invasive alien species swim freely within the range of the two subpopulations, we recognise these as just two locations based on the threat: "alien species invasion". The total AOO for both subpopulations is calculated at $80 \mathrm{~km}^{2}$, while the EOO is $574 \mathrm{~km}^{2}$. Considering that the AOO is less than $500 \mathrm{~km}^{2}$, and the EOO is less than $5,000 \mathrm{~km}^{2}$, in line with the IUCN Red List criteria (IUCN, 2012), O. croaticus should be listed as endangered (EN). Furthermore, the species is exposed to continuing reductions in habitat quality and meets the criteria $\mathrm{B} 1 \mathrm{ab}$ (iii) and $\mathrm{B} 2 \mathrm{ab}$ (iii), supporting its listing in this category.

\section{SAŽETAK}

\section{UGROŽENE VRSTE RIBA U SVIJETU: Orsinogobius croaticus (Mrakovčić, Kerovec, Mišetić and Schneider, 1996) (Teleostei: Gobiidae)}

Orsinogobius croaticus je slatkovodna riba s malom i ograničenom rasprostranjenosti u Jadranskom bazenu u Hrvatskoj i Bosni i Hercegovini gdje nastanjuje hladne krške rijeke i izvore. Glavne prijetnje populacijama su fragmentacija staništa, smanjena kakvoća staništa i unošenje stranih vrsta. Predlažu se preporuke zaštite za poboljšanje učinkovitog očuvanja staništa i proširenje znanja o ovoj vrsti.

Ključne riječi: Vrgoračka gobica, fragmentacije, zaštita staništa

\section{REFERENCES}

Ćaleta, M., Buj, I. Mrakovčić, M., Mustafič, P., Zanella, D., Marčić, Z., Duplić. A., Mihinjač, T., Katavič, I. (2015): Endemic Fishes of Croatia. Croatian Environment Agency, Zagreb, $116 \mathrm{pp}$.

Crivelli, A.J. (2006): Knipowitschia croatica. The IUCN Red List of Threatened Species 2006: e.T11031A3241026. www.iucnredlist.org. Downloaded on 29 March 2016

Geiger, M.F., Herder F., Monaghan, M.T., Almada, V., Barbieri, R., Bariche M., Berrebi, P., Bohlen, J., Casal-lopez, M., Delmastro, G. B., Denys, G. P. J., Dettai, A., Doadrio, I., Kalogianni, E., Kärst, H., Kottelat, M., Kovačić, M., Laporte, M., Lorenzoni, M., Marčić, Z., Özulu , M., Perdices, A., Perea, S., Persat, S., Porcelotti, S., Puzzi, C., Robalo, J., Šanda, R., Schneider, M., Šlechtová, V., Stoumboudi, M., Walter. S., Freyhof, J. (2014): Spatial heterogeneity in the Mediterranean biodiversity hotspot affects barcoding accuracy of its freshwater fishes. Molecular Ecology Resources, 14, 1210-1221.

IUCN (1996): 1996 IUCN Red List of Threatened Animals. IUCN, Gland, Switzerland and Cambridge, UK. 448 pp.

IUCN (2012): IUCN Red List Categories and Criteria: Version 3.1. Second edition. Gland, Switzerland and Cambridge, UK: IUCN. iv + 32pp.

Kottelat, M., Freyhof, J. (2007): Handbook of European Freshwater Fishes. Kottelat, Cornol, Switzerland and Freyhof, Berlin, Germany, 569-570.

Miller, P. J. (2004): The Freshwater Fishes of Europe. AULAVerlag $\mathrm{GmbH}$ Wiebelsheim. Vol. 8 / II Gobiidae 2, 365369.

Mrakovčič, M., Kerovec, M., Mišetič, S., Schneider, D. (1996): Description of Knipowitschia punctatissima croatica, (Pisces: Gobiidae), a new freshwater goby from Dalmatia, Croatia. In: Conservation of Endangered Freshwater Fish in Europe. A. Kirchhofer, D. Hefti (Eds). Birkhauser Verlag, Basel, 311- 319.

Mrakovčić, M., Brigić, A., Buj, I., Ćaleta, M., Mustafić, P., Zanella, D. (2006): Red Book of Freshwater Fish of Croatia. Ministry of Culture, State Institute for Nature Protection, Zagreb, Croatia [In Croatian with English introduction].

Šanda, R. Kovačić, M. (2009). Freshwater gobies in the Adriatic drainage basin of the western Balkans. Annales. Series historia naturalis, 19, 1, 1-10. 
Zanella, D. (2007): Biological and ecological characteristics of Knipowitschia croatica Mrakovčić et al. 1994 (Actinoperygii, Gobiidae) in the Matica River (Vrgorac). Doctoral thesis. University of Zagreb, Faculty of Science, Division of Biology, 73-98 [In Croatian].

Zanella, D., Mrakovčić, M., Zanella, L.N., Miletić, M., Mustafić, P., Ćaleta M., Marčić Z. (2011): Reproductive biology of the freshwater goby Knipowitschia croatica Mrakovčić, Kerovec, Mišetič and Schneider 1996 (Actinopterygii, Gobiidae). Journal of Applied Ichthyology, 27, 1242-1248.

Zanella, D., Kovačić, M. (2014): Program praćenja stanja za vrgoračku gobicu (Knipowitschia croatica) u Hrvatskoj. Izvještaj za Državni zavod za zaštitu prirode. Hrvatsko ihtiološko društvo, Zagreb. 